DOI https://doi.org/10.30525/978-9934-588-81-5-1.47

\title{
СУЧАСНІ ПРОБЛЕМИ НАДАННЯ ПЕРВИННОЇ МЕДИЧНОЇ ДОПОМОГИ ПАЦІЕНТАМ, ЯКІ ВЖИВАЮТЬ АЛКОГОЛЬ ЗІ ШКІДЛИВИМИ НАСЛІДКАМИ В ЗАГАЛЬНІЙ ПРАКТИЦІ СІМЕЙНОЇ МЕДИЦИНИ
}

\author{
Салдень В. I. \\ аспірант очної денної форми навчання третього року навчання \\ ДУ «Науково-дослідний інститут психіатрії \\ Міністерства охорони здоров'я України» \\ м. Київ, Украӥна
}

За даними вітчизняних авторів в загальній структурі поширеності психічних захворювань порушення психіки і поведінки внаслідок шкідливого вживання психоактивних речовин (ПАР), зокрема, алкоголю складають 41,6\% [1, 2]. Згідно з Концепцією «Державної політики щодо попередження шкідливих наслідків зловживання алкоголем на період 2012-2020 рр.» службам охорони здоров'я належить центральна роль у протидії шкоді, заподіяній зловживанням алкоголем. Тому, фахівці закладів охорони здоров'я повинні забезпечити якісну профілактику та результативне лікування психічних і поведінкових порушень, викликаних вживанням алкогольних напоїв. Проведення скринінгу для виявлення небезпечного та шкідливого вживання алкоголю у пацієнтів на рівні первинної медико-санітарної допомоги є одним з першочергових заходів, рекомендованих даною Концепцією [3].

Діяльність сімейного лікаря амбулаторно-поліклінічного закладу має бути спрямована на виявлення шкідливого вживання алкоголю при зверненні соматичних хворих за медичною допомогою.

Сімейний лікар амбулаторно-поліклінічного закладу визначає показання та обсяг необхідних діагностичних досліджень для уточнення факту шкідливого вживання алкоголю, наявності або відсутності адиктивного статусу, здійснює відбір пацієнтів наркологічного профілю, які потребують спеціалізованих видів лікування, веде динамічне спостереження за такими хворими [4].

За період 2017-2018 рр. було обстежено 560 хворих, які звертались 3 соматичними скаргами в заклади первинної медико-санітарної допомоги, зокрема, КНП «ЦПМСД №1» Солом'янського району м. Києва. Пацієнти, за умови інформованої згоди, були обстежені із застосуванням розробленої нами уніфікованої карти. У даного контингенту вивче- 
но клініко-анамнестичні, соціально-демографічні, психодіагностичні, клініко-психопатологічні показники та адиктивний статус за допомогою тесту AUDIT.

Результати обстеження за AUDIT-тестом показали, що серед усіх обстежених значну кількість становили особи із ступенем «С» (вживання алкоголю зі шкідливими наслідками) - 240 осіб (42,8\%). Серед відібраних 240 пацієнтів за методикою PHQ-9 (1999) виявлено, що значна кількість респондентів мала прояви депресії (від легкого до помірнотяжкого рівня - 81,7\% ). За методикою HADS (1983) встановлено, що більшість обстежених мали рівень тривоги та депресії категорії межових станів (41,7\%; 47,5\% відповідно). «Шкала реактивної і особистісної тривожності» Ч. Д. Спілбергера - Ю. Л. Ханіна (1976), виявила наявність як помірної особистісної, так і ситуативної тривожності. За шкалою самооцінки депресії В. Зунге (1965) встановлено наявність легкого рівню депресії також у більшості обстежених. За даними методики «САН» (1973) можна зробити висновок, що всі середні показники за трьома видами дослідження відповідали «неблагополучній» категорії.

Таким чином, на основі результатів клініко-анамнестичних, соціально-демографічних, клініко-психопатологічних та психодіагностичних досліджень нами розроблено систему психотерапії і психопрофілактики в комплексному лікуванні соматичних хворих з психічними і поведінковими порушеннями, які вживають алкоголь зі шкідливими наслідками.

\section{Література:}

1. Табачніков C.I., Харченко С.М., Осуховська О.С. та співавт. Психодіагностичні методи виявлення вживання ПАР у хворих соматичного профілю в умовах сімейної медицини Науково-інформаційний вісник Академї̈ наук вищої освіти Украӥни. 2018. № 3 (105). С. 16-24.

2. Линник С. Реалізація в Україні Глобальної стратегії ВОО3 «Скорочення шкідливого споживання алкоголю». Науковий вісник «Демократичне врядування». 2012. № 10. 8 с.

3. Грузєва Т. С., Замкевич В. Б. Стратегічні напрями боротьби 3 небезпечним та шкідливим вживанням алкоголю в документах Всесвітньої організації охорони здоров'я. Вісник соціальної гігієни та організації охорони здоров’я Украӥни. 2019. № 3 (81). С. 124-133.

4. Global Information System on Alcohol and Health (GISAH): levels of consumption [online database]. Geneva: World Health Organization; 2018 [Electronic resource]. - Access mode : http://www.who.int/ gho/alcohol/consumption_levels/en/ 